\title{
RESEARCH AND SCIENTIFIC SERVICES IN EAST AFRICA
}

\begin{abstract}
A SURVEY of the organization of the interterritorial research and scientific services in Kenya, Uganda, Tanganyika and Zanzibar, particularly those which are responsible to the East Africa High Commission, was completed by Dr. E. B. Worthington in December 1951 while serving under the Administrator to the High Commission and before he was appointed secretary-general of the Scientific Council for Africa South of the Sahara. The work has now been published under the title of "Survey of Research and Scientific Services in East Africa, 1947-1956"*. Besides describing develop. ments up to the end of 1951 , it records Dr. Worthington's views as to how these services should be developed during the next five years within the limited financial provision which is foreseeable to-day. The account is, in fact, both a report on four years of progress and a revision of the development plan outlined in Dr. Worthington's unpublished report of January 1948.
\end{abstract}

Although finance is a dominating factor in determining how much scientific work can be undertaken, the four references to finance are in general terms and of such a nature as to enhance the importance of the publication of the survey at this juncture. It directs attention to matters which require careful consideration in connexion with the proposals now under active consideration for the further extension of funds for research under the Colonial Development and Welfare Acts. Moreover, it indicates considerations which bear closely on research and scientific services not only in East Africa but also in other territories receiving technical and scientific assistarne, whether under the Colombo Plan or the Expanded Programme for Technical Assistance of the United Nations.

Dr. Worthington makes no exaggerated claims for the planning of scientific work, nor does he imply that research is susceptible of detailed planning many years in advance. It is possible and necessary, however, to plan well ahead for the provision of facilities and staff, and to indicate broad problems to which solutions are required. Such planning is, in fact, an essential element in producing the scientific and administrative elimate in which research flourishes -a climate of confidence. Where Dr. Worthington leans to regional organization, it is for the sake of the continuity and stability which are indispensable if confidence is to be engendered. The full weight of his authority can be put behind the pleas which have been made for continuity and greater assurance in the support of the Technical Assistance Programme. "Research which is subject to the hazard of inter. muption on financial ground cannot be fully productive," he writes, and pointing out that many forms of research need to be planned as much as ten years ahead, he emphasizes the importance of fresh provision being made by Parliament for Colonial research well before the expiry of the existing Acts. His argument is enforced by the observations which Dr. Worthington makes on regional organization of science as against a territorial basis. These advant-

- East African High Commission. A Survey of Research and Scientific Services in East Africa 1947-1956. (Paper No. 6.) By E. B. Worthington. Pp. ill +79 . (Nairobi : East African High Com-
migsion, n.d.) ages, such as the ability to view the technical problems of the territories as a whole, the means to afford a large staff of specialists and consequent greater confluence of thought on a single problem, and the greater attractiveness to first-class scientists and scientific visitors, will be seriously affected by uncertainty as to future resources. For the present, however, while the territorial Governments themselves are separate, most of the executive side of scientific work will continue to be arranged territorially and the regional scientific services to be limited to advisory functions and the investigations necessary as a basis for advice.

Dr. Worthington gives a summary of the East Africa Regional Scientific Services during 1952, which employed 151 professional officers with a recurrent expenditure of just under $£ 750,000$. Of this, a little more than $£ 100,000$ each was expended on meteorology, on agriculture, on the tsetse flies and trypanosomiasis organization, and on health and medicine, just over $£ 50,000$ on fisheries, a little less on animal health, and $£ 60,000$ on statistics. Only in agriculture and forestry, in health and medicine and in the tsetse flies and trypanosomiasis organization were more than twenty professional officers employed, and Dr. Worthington directs attention to the wide range in the average cost of supporting a professional officer, including his assistants, facilities and all overheads. Due to the differen'ces in type and conditions of work, this may vary from less than $£ 2,000$ per officer in sociology to more than $£ 10,000$ in meteorology and the desert locust survey, and accordingly the efficiency of a research organization cannot be judged merely by its cost per scientist.

These observations are pertinent not only for the services organized under the East Africa, High Commission and the territorial services with which they are related, but also for the organizations and agencies concerned with scientific work elsewhere in Africa, with which the exchange of knowledge, and even closer relations, is of increasing importance. Dr. Worthington reviews briefly these relations, and glances also at the arrangements by which technical and scientific assistance is received from the United States and at the relations between the work in East Africa and the Colonial Office and scientific work in the United Kingdom. The clear picture he gives of all these relations and of their implications is of value to all concerned with such work, but to scientists in general the major interest of his survey will be the review he gives of the current position of the principal fields of scientific investigation in East Africa and his estimate of the future needs in each of these fields. As a background to this review he gives a tabular summary showing the services which at present function in these fields, the administering authorities and the sources from which they are financed.

Considering first the subject of surveys and maps, Dr. Worthington concludes that the full needs of East Africa are unlikely to be met by the publication of atlases and maps already in preparation, and that, following the international geological and tsetse fly maps of Africa, a standard scale of $1: 5,000,000$ is probably the best for initial purposes to illustrate 
other subjects. During the next few years the object should be to publish adequate special subject maps, either for East Africa as a whole or for each territory separately, with larger scales for Uganda and Zanzibar. Most of the consultation involved in collecting, analysing and presenting the necessary data could be secured by giving adequate financial assistance to the Geographical Department of Makerere, with close contact with the Central Directorate of Colonial Surveys and the Territorial Survey Departments.

In regard to geology and archæology, Dr. Worthington considers that even with the aid already received from the United States under the Economic Cooperation Assistance Administration, the individual territories are unlikely ever to be able to afford a geological survey large enough to be truly efficient. No adequate provision yet exists for archæology, and apart from the importance of the subject to culture in general, and the value of the archæological wealth to the tourist industry, Dr. Worthington points out that research in this field is desirable because of the importance of Tertiary and Quaternary geology in connexion with water supplies and mineral resources. The projects advanced during 1944-48 for a full-scale inter-territorial archæological survey are at present in abeyance, and Dr. Worthington urges that several young arehæologists should be set to work in East Africa while the guidance of specialists of international reputation is still available.

In meteorology, heavy routine duties have precluded much research by the East African Meteorological Department, but a wide range of research is desirable, particularly where meteorology impinges on questions of water supply, agriculture and health : recent work has indicated, for example, that the fundamental study of air masses is likely to be of the utmost importance in connexion with the problem of the desert locust. Water supply and agricultural interests have strongly supported the formation of a small climatological research section. The importance to East Africa of adding a rainfall research unit to the Meteorological Department can scarcely be overstressed, and the growing importance of hydrology and of relating it to climatic conditions has already led to proposals for an inter-territorial hydrological bureau.

In regard to background biology, Dr. Worthington suggests that three steps are desirable for dealing with the difficult situation in systematic entomology. First, a building for systematic entomology should be erected in the Coryndon Museum grounds, similar in design to the East African Herbarium, in which should be pooled all major collections of insects and related groups: Secondly, the building would be staffed with the entomologists from the Coryndon Museum and other entomologists working on systematics recruited to the inter-territorial research organizations. Thirdly, the Colonial Office might consider a scheme for entomology similar to that already made for the flora. The appointment of a mammalian zoologist to the Coryndon Museum is considered to be of high priority, and in marine and freshwater zoology there is almost unlimited scope for studies in background biology and systematics.

The East African Agriculture and Forestry Research Organization is the largest body of this character in East Africa and has completed its first phase of development; nevertheless, with a total of twenty-seven scientific staff it is far short of the thirty-five which were to be recruited by 1952 . It seems probable that it will only be increased to thirty-two or thirty- three by 1955 instead of to the forty-five originally envisaged as the minimum for a balanced research programme. During the remainder of the period of Colonial Development and Welfare Funds, up to March 1956, the Organization will accordingly have to concentrate on soil science (including microbiology of soils), on plant pathology and on animal husbandry, with a few officers on forestry problems; the original plans for work on plant breeding and entomology will have to be deferred. The Organization is in close touch with the East African Veterinary Research Organization, the new headquarters of which since September 1953 are also at Muguga South, with main laboratory and field-work at Muguga North. When all the latter facilities are available, the staff is expected to increase from the ten scientific officers and thirteen European assistants of 1952 to twenty scientific officers and twenty-five European technical and administrative officers. Together the establishments at Muguga North and South will then constitute one of the largest scientific centres in Africa.

Dr. Worthington notes the work being carried out by the East African Tsetse Flies and Trypanosomiasis Research Organization; by the Desert Locust Survey, stressing the importance of allowing research work by this body to proceed unimpeded by concentration on control measures; and by the Colonial Insecticides Unit. Under problems concerned with the control and conservation of wild animals, he supports two proposals from the Game Sub-Committee set up by the Colonial Office as being of inter-territorial, if not international, significance. A research team, consisting of a biologist, a veterinary research officer, a botanical ecologist and a game ranger, should be recruited to investigate and collect information on game problems in one area, for example, Tanganyika, to supervise the practical work involved in setting up experimental game fences and to undertake research into game management. A survey should also be made of all information available on scientific questions relating to the mammalian fauna of East Africa. A worker has already been appointed to make this survey; but, although details for a research unit for the first project were worked out towards the end of 1951, the East African Governments, while expressing interest, withdrew financial support.

In fisheries research the chief need of the interterritorial marine fishery research unit at Zanzibar is for the larger research vessel, properly equipped for marine research, contemplated in the original plans. In freshwater fishery the Lake Victoria Fisheries Service is only now starting to introduce and administer inter-territorial legislation designed to assist the development of the industry and the conservation of stocks; the third or technological phase will be to introduce new or improved methods of fishing, to tap new resources and to organize better methods of preserving fish and of marketing and distribution. Up to now the East African Industrial Research Board has been financed by the East African Governments without grants from Colonial Development and Welfare Funds, although Tangan. yika withdrew in 1947 when its own government chemical laboratory was enlarged, and pending the establishment of an East African Industrial Research Organization. Although a Director of East African Industrial Research was appointed in April 1951, details of the new organization and the method of financing it are not yet finally settled. Present proposals contemplate four units, of some five or six 
scientists each, for chemistry and chemical engineering, for building research, for road research and for metallurgical work: the first, with the directorate, and the second would be in Nairobi, the third in Tanganyika and the fourth in Uganda.

Reviewing inter-territorial research in health and medicine, which is organized in several independent units or institutes, each separately responsible to the Administrator of the High Commission, with the East African Bureau of Research in Medicine and Hygiene as co-ordinating agency, Dr. Worthington suggests that the East Africa Medical Survey may in the future either turn its primary concern from investigation to the application of the results, or hand over application to the territorial departments and extend its investigations to other African areas for comparison with work now being conducted in Sukumaland. If the Filariasis Research Unit terminates in 1954, its facilities will presumably be absorbed into those of the Medical Survey, but the Malaria Unit should continue, if not expand, and the Virus Research Unit at Entebbe likewise has a great field of research open to it. Future planning, however, while depending on the results of the Medical Survey, should be designed particularly towards the development of preventive techniques, but should include provision for fuller investigation on an inter-territorial basis of such problems as nutrition, schistosomiasis, snail vectors, silicosis, tuberculosis and plague, and especially the effect upon the numbers, activity and output of a population of large-scale measures for control of disease. This matter is closely related to the demographic studies of the East African Statistical Department, and Dr. Worthington suggests that the possibility of creating an "operational research unit" to assess the interaction of all factors on the general economy of East Africa should be kept in mind. The East African Institute of Social Research and research workers connected with it are at present devoting special attention to the study of the development of local government in African societies. Dr. Worthington directs attention to the need for good libraries and information services, with which East African science is not yet well equipped; but though he advocates a publicity policy in which due regard is paid to the comparative responsibilities of regional services as compared with territorial departments, he suggests that in East Africa it is better to concentrate on enlarging and improving the existing scientific or technical periodicals than to establish new ones.

Dr. Worthington's most important references to finance are to be found in his final section, which includes a tabular summary forecast of East African Regional Scientific Services in 1956. Recurrent expenditure is put at no more than $£ 868,000$, with some 182 professional officers, meteorology $(\mathfrak{1 2 0 , 0 0 0 )}$ and tsetse flies and trypanosomiasis $(£ 118,000)$ being the largest items, while on four others-agriculture and forestry, animal health, locust survey, and health and medicine expenditure is a little above or below $£ 100,000$. This represents an increase of 17 per cent in four years, in accordance with a period of consolidation, rather than of expansion, and one in which the proportion of total effort devoted to research on the productive services has increased slightly with reduction elsewhere. Moreover, expenditure in East Africa represents about one-third of the Colonial Development and Welfare Research Funds already committed, although the region represents only about one-fifth of the Colonial Empire. Dr.
Worthington recognizes that the solution of major problems during the next five years or so may permit some readjustments, for example, possibly a reduction in the size of the. Tsetse Flies and Trypanosomiasis Organization; but although the East African Governments may be expected to increase their expenditure on research, the percentage of expenditure on research in their rapidly expanding budgets is unlikely to exceed the present three per cent. Continuing support from Colonial Development and Welfare Research Funds will be required, and finally Dr. Worthington pleads that, in the future organization and finance of research in East Africa, regard should be had to the academic system of picking really good men and giving them full freedom of action.

\section{WEIZMANN MEMORIAL CONVOCATION}

$T$

O mark the first anniversary of the death of the late President Weizmann, a number of events of scientific interest took place at the Weizmann Institute of Science at Rehovoth, Israel. On November 3, the new building of the Department of Experimental Biology was formally opened (p. 68), and at the same time the corner-stone of the Institute of Physics laid. On the afternoon of the same day, honorary fellowships of the Weizmann Institute were conferred upon the following guests : Prof. Niels Bohr (Copenhagen), Dr. Ernst E. Chain (Rome), Dr. Herman F. Mark (Brooklyn), Prof. Linus C. Pauling (Pasadena) and Dr. F. Peyton Rous (Now York). Following this ceremony, Prof. Niels Bohr gave an address on "Modern Physics and Philosophy".

The occasion was taken to hold a number of scientific symposia. In a biological symposium, Dr.' Peyton Rous gave a general account of the "Natural History of Cancer", Prof. I. Berenblum (Rehovoth) spoke on the mechanism of carcinogenesis, Dr. M. Shelesnyak (Rehovoth) spoke on recent work on the mechanism of nidation in the mammalian uterus, and Dr. L. Sachs (Rehovoth) presented a genetical analysis of evolution.

In a symposium on polymers and proteins, Prof. Mark described recent developments in the study of block copolyners; Prof. A. Katchalsky (Rehovoth) gave an account of the rheological properties of polyelectrolyte gels and Prof. Pauling spoke on the $\alpha$-helix structure of protein.

There was a symposium on microbiology and biochemistry in which Prof. Chain deseribed the role of insulin and other substances in glycogen formation; Prof. E. Katchalsky (Rehovoth) spoke on the polymerization accompanying the action of proteolytic enzymes on poly- $\alpha$-amino-rcids, and Dr. S. Hestrin (Jerusalem) on the synthesis and degradation of polysaccharides.

In the physical symposium, Prof. Niels Bohr gave a general introduction to modern atomic physics (electronic and nuclear) and its relation to molecular structure questions; Dr. A. Bohr (Copenhagen) described recent results, both theoretical and experimental, on nuclear rotational levels; and Prof. G. Racah (Jerusalem) spoke on angular correlation between nuclear radiation. Dr. S. Rozental (Copenhagen) wound up the symposium with an account of the organization and work of the Institute of Theoretical Physics in Copenhrgen. 